\title{
The effects of surface roughness, chloride, and molybdate on the corrosion behavior of iron in bicarbonate/carbonate solutions
}

\author{
Ahmed S. Alshamsi,* Afra G. AlBlooshi, Almaha S. Alshamsi, \\ Asma Y. Alkaabi, Yasmeen S. Elnasiri and Mouza M. Aldhaheri \\ Department of Chemistry, College of Science, United Arab Emirates University (UAEU), \\ Al Ain, UAE \\ *E-mail: $\underline{\text { a.alshamsi@uaeu.ac.ae }}$
}

\begin{abstract}
The effects of surface roughness, chloride ions, and molybdate ions on the corrosion behavior of pure iron was thoroughly investigated in bicarbonate/carbonate solutions at $22^{\circ} \mathrm{C}$. Open circuit potential versus time, polarization resistance versus time, potentiodynamic polarization, electrochemical impedance spectroscopy (EIS), and scanning electron microscopy (SEM) were used for this investigation. The results demonstrated the presence of up to $2 \%$ molybdate ions does not enhance the corrosion resistance of pure iron in chloride-free bicarbonate/carbonate solutions. Moreover, molybdate ions and surface roughness have little effect on the passivity of iron in chloride-free bicarbonate/carbonate solutions. The effect of molybdate and surface roughness, however, changed in the presence of chloride. Iron with relatively smooth surface finish showed better corrosion resistance than iron with relatively rough surface finish. Moreover, the presence of molybdate improved the corrosion resistance of iron when chloride was present. The passive current densities decreased while the pitting potential increased in the presence of molybdate for both smooth and rough surface finish. SEM images taken after two days of immersion (at the open circuit potential) in chloridecontaining solutions did not show any signs of pitting corrosion. SEM images taken after the polarization tests showed pitting corrosion in chloride-containing solutions in the absence of molybdate. Interestingly, SEM images taken after polarization did not show signs of pitting in chloride-containing solutions when $2 \%$ molybdate was present. The presence of molybdate enhanced the iron resistance to localized corrosion. Finally, the constant phase element can be treated as a non-ideal capacitor in chloride-free solutions for both the relatively smooth and relatively rough surface finish. In chloride-containing solutions, the constant phase element can be treated as a non-ideal capacitor for the relatively smooth surface finish, but not the relatively rough surface finish.
\end{abstract}

Keywords: iron, corrosion, pitting, bicarbonate, carbonate, chloride, molybdate, electrochemical impedance spectroscopy, surface roughness, SEM.

Received: September 18, 2019. Published: October 12, 2019

doi: $\underline{10.17675 / 2305-6894-2019-8-4-4}$ 


\section{Introduction}

Passivity and passivity breakdown of metals and alloys have been extensively reported in the literature. J. Soltis reviewed the passive film formation and breakdown in metallic materials including iron alloys [1]. Angathevar Veluchamy et al. published a critical review on the passive film formation and breakdown on iron electrode under different conditions including the effect of halides [2]. Reinforcing steel bars (rebars) can be exposed to carbonate, bicarbonate, and chloride [3]. Moreno et al. reported a minimum $\mathrm{Cl}^{-}$ concentration of $0.05 \%$ is required in order to induce passivity breakdown of reinforced steel in simulated concrete pore solution of bicarbonate/carbonate [3]. Yong Teck Tan et al. concluded that bicarbonate/carbonate ions have an inhibitive effect on the pitting corrosion of AISI 1020 carbon steel tested in saturated $\mathrm{Ca}(\mathrm{OH})_{2}$ in the presence of chloride ions [4]. N.N. Andreev et al. concluded that the corrosion of reinforced steel occurs early in the course of steel hardening in chloride-containing concrete. Moreover, the growth rate of corrosion spots decreases significantly once the curing process is completed [5]. I.A. Gedvillo et al. concluded that steel is prone to pitting corrosion during the initial stage of concrete hardening with pitting corrosion intensified by the presence of chloride [6].

Molybdate ion $\left(\mathrm{MoO}_{4}^{2-}\right)$ has been gaining widespread acceptance as a non-toxic environmentally friendly inorganic corrosion inhibitor [7]. On the other hand, $\mathrm{MoO}_{4}^{2-}$ has been reported to increase the repassivation rate and to enhance resistance to localized corrosion [8-12]. In acidic chloride-containing solutions, the mechanism of inhibition by molybdate $\left(\mathrm{MoO}_{4}^{2-}\right)$ is thought to be a process of ion exchange, followed by the formation of an insoluble film reported to be ferric molybdate $\left(\mathrm{FeMoO}_{4}\right)$. The adsorption produces a layer that resists the corrosive effects to other anions, particularly chlorides and sulfates. The precipitate hinder the transpassive reaction leading to lower current densities [11]. Furthermore, relatively low $\mathrm{MoO}_{4}^{2-}$ concentrations were reported to decrease the corrosion resistance of various metals and alloys [8, 13-18]. Yong Teck Tan et al. reported that molybdate ions inhibited pitting corrosion of AISI 1020 carbon steel in $\mathrm{Cl}^{-}$-containing $\mathrm{Ca}(\mathrm{OH})_{2} / \mathrm{NaHCO}_{3}$ solutions [19]. It is worth mentioning that the tests were conducted under the open circuit potential conditions only.

Ilevbare and Burstein reported that the presence of $\mathrm{MoO}_{4}^{2-}$ affected both passivity and pit nucleation by deactivating the sites at which pit formation occurred and by reducing the pit size; consequently, becoming more difficult for pits to develop into stable ones [20].

Furthermore, corrosion behavior is influenced by surface roughness and texture [21]. Burstein and Pistorius reported that the nucleation rate of metastable pits of 304 stainless steel in solutions containing $\mathrm{Cl}^{-}$ions increased with increasing surface roughness [22]. Wang et al. reported an increase in charge transfer resistance $\left(R_{\mathrm{ct}}\right)$ values with decreasing roughness for mild steel tested in ammonium chloride $\left(\mathrm{NH}_{4} \mathrm{Cl}\right)$ solution [23]. Alshamsi and Alblooshi reported that the corrosion rate of $\mathrm{Fe}$ increased with increasing surface roughness in $0.1 \mathrm{M} \mathrm{HCl}$ and in $0.1 \mathrm{M} \mathrm{H}_{2} \mathrm{SO}_{4}$ [18]. 
The current work investigates the corrosion behavior of pure $\mathrm{Fe}$ in $0.3 \mathrm{M} \mathrm{NaHCO}_{3}+$ $0.1 \mathrm{M} \mathrm{Na}_{2} \mathrm{CO}_{3}$. The solution simulates carbonated concrete [3]. Moreover, the effects of surface roughness, the presence of $\mathrm{MoO}_{4}^{2-}$ and the presence of $\mathrm{Cl}^{-}$on the corrosion behavior are discussed.

The novelty of this work is in the use of pure $\mathrm{Fe}$ instead of carbon steel in carbonate/bicarbonate solutions. The use of pure iron instead of carbon steel minimizes the effect of inclusions on the passivity breakdown. Moreover, the current work examines the effect of $\mathrm{MoO}_{4}^{2-}$ as a corrosion inhibitor in the absence and presence of $\mathrm{Cl}^{-}$ions using different surface roughness.

\section{Experiments}

Commercial $\mathrm{Fe}(99.99+\%)$ was tested in $0.3 \mathrm{M} \mathrm{NaHCO}_{3}+0.1 \mathrm{M} \mathrm{Na}_{2} \mathrm{CO}_{3}$ solutions in the absence and presence of $\mathrm{MoO}_{4}^{2-}$ and/or $\mathrm{Cl}^{-}$at $22 \pm 1^{\circ} \mathrm{C}$. An Fe rod, $2 \mathrm{~mm}$ in diameter, was coated with epoxy, but the cross-sectional area $\left(0.0314 \mathrm{~cm}^{2}\right)$ was exposed to the testing solution. The sample was wet-ground using only grit paper P120 in order to maintain a relatively rough surface area. Alternatively, the sample was wet-ground using P120 followed by P320, P800, and finally with P1000 in order to maintain a relatively smooth surface area. The sample was cleaned with deionized water in ultrasound bath, washed with deionized water, and placed in a 3-electrode cell with platinum $(\mathrm{Pt})$ as a counterelectrode and saturated $\mathrm{Ag} / \mathrm{AgCl}$ electrode as the reference electrode. Two sets of experiments were conducted. In one set, the open circuit potential versus time (OCP versus $t$ ) was conducted first, followed by electrochemical impedance spectroscopy (EIS). In the other set, OCP versus $t$ was conducted first, followed by the polarization resistance versus time ( $R_{\mathrm{p}}$ versus $\left.t\right)$, and finally by the potentiodynamic polarization measurements. The OCP was monitored for one hour prior to each experiment upon the immersion in the solution. The $R_{\mathrm{p}}$ versus $t$ measurements were conducted at a scanning rate of $0.1 \mathrm{mV} \mathrm{s}{ }^{-1}$ with experiments conducted at $\pm 20 \mathrm{mV}$ versus the corrosion potential $\left(E_{\mathrm{c}}\right)$. Four data points were collected per $R_{\mathrm{p}}$ versus $t$ experiment. EIS experiments were conducted using an applied alternating current (AC) potential of $10 \mathrm{mV}$ with frequencies ranging from 0.005 to $100,000 \mathrm{~Hz}$. The potentiodynamic polarization experiments were initiated at $-250 \mathrm{mV}$ versus the corrosion potential $\left(E_{\mathrm{c}}\right)$, scanned to $+700 \mathrm{mV}$ using a scanning rate of $1.0 \mathrm{mV} \mathrm{s}^{-1}$. Magnetic stirring at a constant rate was maintained in all experiments. On average, three independent experiments were conducted for all specimens. Data were collected automatically with the aid of a potentiostat/galvanstat (Gamry G750). All data analyses and extrapolations were performed using Gamry corrosion software (Gamry Echem Analyst). The samples' surface morphologies were examined using scanning electron microscopy (SEM). The samples were cleaned in an ultrasound bath prior to SEM examination. Table 1 lists the solutions used in this study. 
Table 1. Compositions of the solutions used in this study.

\begin{tabular}{cc}
\hline Solution & Composition \\
\hline 1 & $0.3 \mathrm{M} \mathrm{NaHCO}_{3}+0.1 \mathrm{M} \mathrm{Na}_{2} \mathrm{CO}_{3}$ \\
2 & $0.3 \mathrm{M} \mathrm{NaHCO}_{3}+0.1 \mathrm{M} \mathrm{Na}_{2} \mathrm{CO}_{3}+1 \% \mathrm{Na}_{2} \mathrm{MoO}_{4}$ \\
3 & $0.3 \mathrm{M} \mathrm{NaHCO}_{3}+0.1 \mathrm{M} \mathrm{Na}_{2} \mathrm{CO}_{3}+2 \% \mathrm{Na}_{2} \mathrm{MoO}_{4}$ \\
4 & $0.3 \mathrm{M} \mathrm{NaHCO}_{3}+0.1 \mathrm{M} \mathrm{Na}_{2} \mathrm{CO}_{3}+1 \% \mathrm{NaCl}$ \\
5 & $0.3 \mathrm{M} \mathrm{NaHCO}_{3}+0.1 \mathrm{M} \mathrm{Na}_{2} \mathrm{CO}_{3}+1 \% \mathrm{NaCl}+1 \% \mathrm{Na}_{2} \mathrm{MoO}_{4}$ \\
6 & $0.3 \mathrm{M} \mathrm{NaHCO}_{3}+0.1 \mathrm{M} \mathrm{Na}_{2} \mathrm{CO}_{3}+1 \% \mathrm{NaCl}+2 \% \mathrm{Na}_{2} \mathrm{MoO}_{4}$ \\
\hline
\end{tabular}

\section{Results and discussion}

\subsection{The corrosion behavior of $\mathrm{Fe}$ in the absence of $\mathrm{Cl}^{-}$ions}

Figure 1(a,b) provides SEM micrographs of the polished smooth (P1000) and the rough (P120) surface, respectively. Figure 2(a,b) shows the OCP versus $t$ for Fe tested in $0.3 \mathrm{M}$ $\mathrm{NaHCO}_{3}+0.1 \mathrm{M} \mathrm{Na}_{2} \mathrm{CO}_{3}$ as a function of $\mathrm{MoO}_{4}^{2-}$ and surface roughness. Figure 2a represents smooth surface finish (P1000) while Figure $2 \mathrm{~b}$ represents rough surface finish (P120).
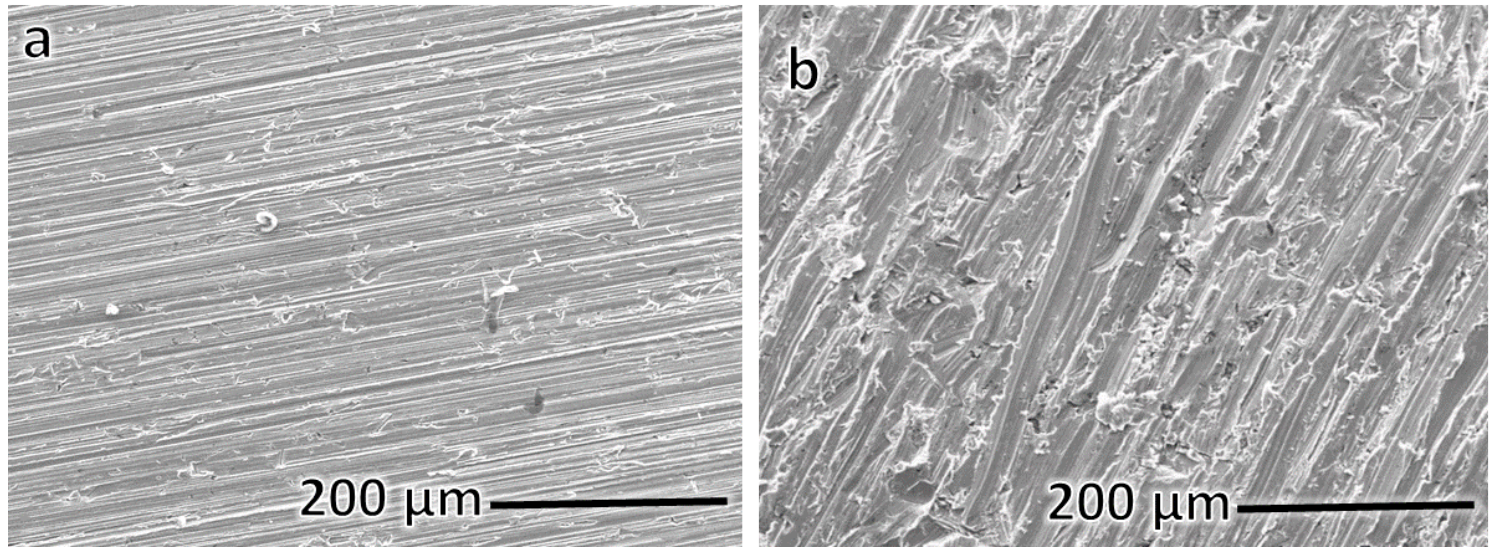

Figure 1. (a) SEM micrograph of polished Fe surface with smooth surface finish (P1000). (b) SEM micrograph of polished Fe surface with rough surface finish (P120).

All curves show steady increase in the OCP with time. Such steady increase in the OCP with time can be attributed to the transformation of pre-existing non-protective film to a stable protective one; the metal passivates in these solutions. Figure $3(\mathrm{a}, \mathrm{b})$ shows $R_{\mathrm{p}}$ versus $t$ curves with the average $R_{\mathrm{p}}$ values reported in Table 2a. Figure 4(a,b) shows the Nyquist plots for the smooth and rough surfaces, respectively. $R_{\mathrm{p}}$ and $\alpha$ values (Table $2 \mathrm{~b}$ ) were obtained by fitting the equivalent electrical circuit to the impedance data from the EIS measurements. Figure 5 shows the circuit used to fit the data. The $R_{\mathrm{p}}$ values in Table $2(\mathrm{a}, \mathrm{b})$ show that the presence of $\mathrm{MoO}_{4}^{2-}$ resulted in little decrease in the $R_{\mathrm{p}}$ values for samples 
with smooth surface finish (slightly higher corrosion rate). For the rough surface finish, the $R_{\mathrm{p}}$ values obtained from the $\mathrm{R}_{\mathrm{p}}$ versus t experiments show little decrease in the presence of $\mathrm{MoO}_{4}^{2-}$ while the $\mathrm{R}_{\mathrm{p}}$ values obtained from the EIS show no change in the presence of $\mathrm{MoO}_{4}^{2-}$. Based on the above discussed results, the presence of $\mathrm{MoO}_{4}^{2-}$ does not enhance the corrosion resistance in these solutions. In fact, small concentration of $\mathrm{MoO}_{4}^{2-}$ might decrease the corrosion resistance.
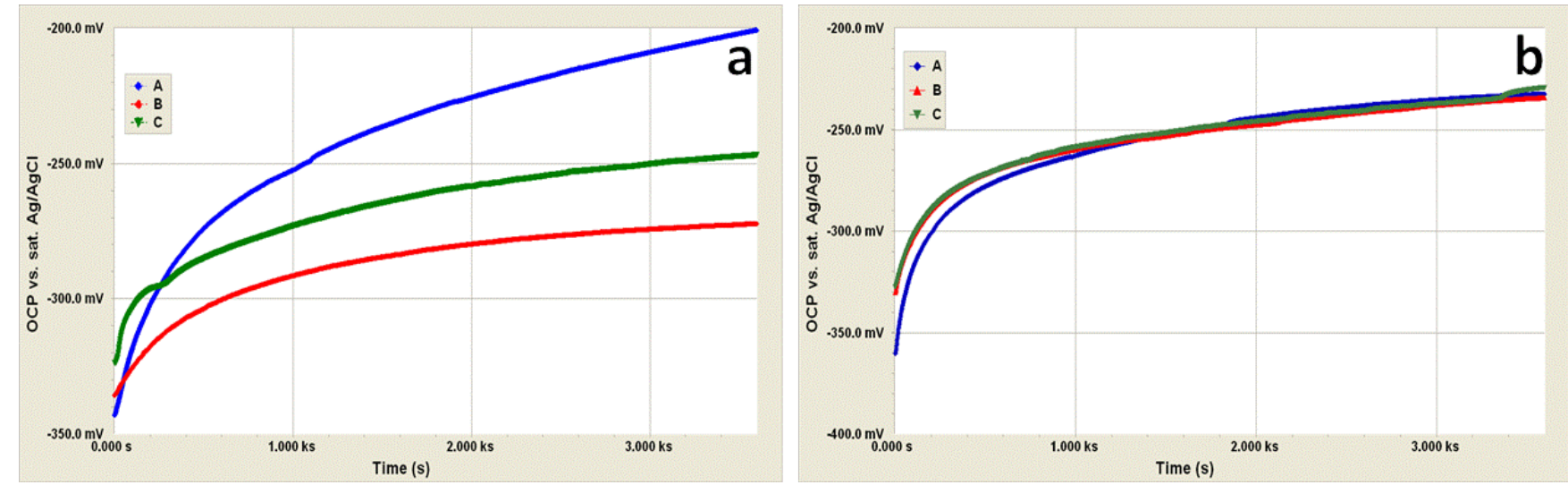

Figure 2. (a) OCP $v$ s. $t$ of $\mathrm{Fe}$ in $0.3 \mathrm{M} \mathrm{NaHCO}_{3}+0.1 \mathrm{M} \mathrm{Na}_{2} \mathrm{CO}_{3}$ with smooth surface finish (P1000) (A: $0 \% \mathrm{Na}_{2} \mathrm{MoO}_{4}, \mathrm{~B}: 1 \% \mathrm{Na}_{2} \mathrm{MoO}_{4}, \mathrm{C}: 2 \% \mathrm{Na}_{2} \mathrm{MoO}_{4}$ ). (b) OCP vs. $t$ of Fe in $0.3 \mathrm{M}$ $\mathrm{NaHCO}_{3}+0.1 \mathrm{M} \mathrm{Na}_{2} \mathrm{CO}_{3}$ with rough surface finish surface (P120) (A: $0 \% \mathrm{Na}_{2} \mathrm{MoO}_{4}, \mathrm{~B}: 1 \%$ $\mathrm{Na}_{2} \mathrm{MoO}_{4}, \mathrm{C}: 2 \% \mathrm{Na}_{2} \mathrm{MoO}_{4}$ ).
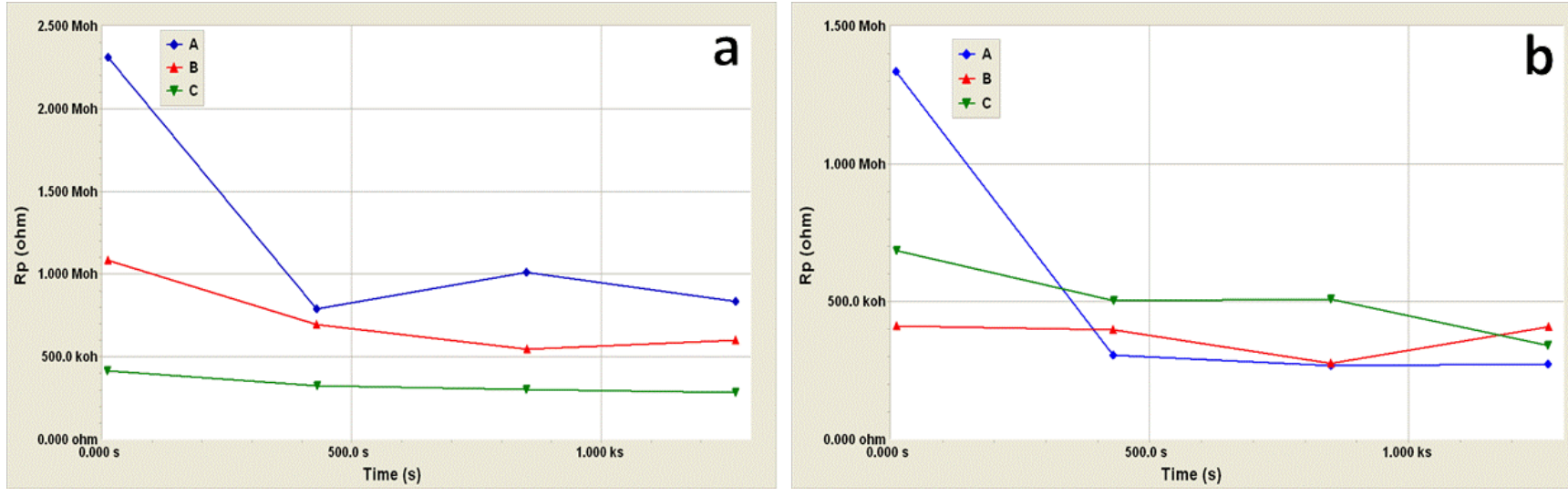

Figure 3. (a) $\mathrm{R}_{\mathrm{p}}$ vs. $t$ of $\mathrm{Fe}$ in $0.3 \mathrm{M} \mathrm{NaHCO}_{3}+0.1 \mathrm{M} \mathrm{Na}_{2} \mathrm{CO}_{3}$ with smooth surface finish (P1000) (A: $0 \% \mathrm{Na}_{2} \mathrm{MoO}_{4}, \mathrm{~B}: 1 \% \mathrm{Na}_{2} \mathrm{MoO}_{4}, \mathrm{C}: 2 \% \mathrm{Na}_{2} \mathrm{MoO}_{4}$ ). (b) $\mathrm{R}_{\mathrm{p}}$ vs. $t$ of Fe in $0.3 \mathrm{M}$ $\mathrm{NaHCO}_{3}+0.1 \mathrm{M} \mathrm{Na}_{2} \mathrm{CO}_{3}$ with rough surface finish (P120) (A: $0 \% \mathrm{Na}_{2} \mathrm{MoO}_{4}, \mathrm{~B}: 1 \%$ $\mathrm{Na}_{2} \mathrm{MoO}_{4}, \mathrm{C}: 2 \% \mathrm{Na}_{2} \mathrm{MoO}_{4}$ ) 


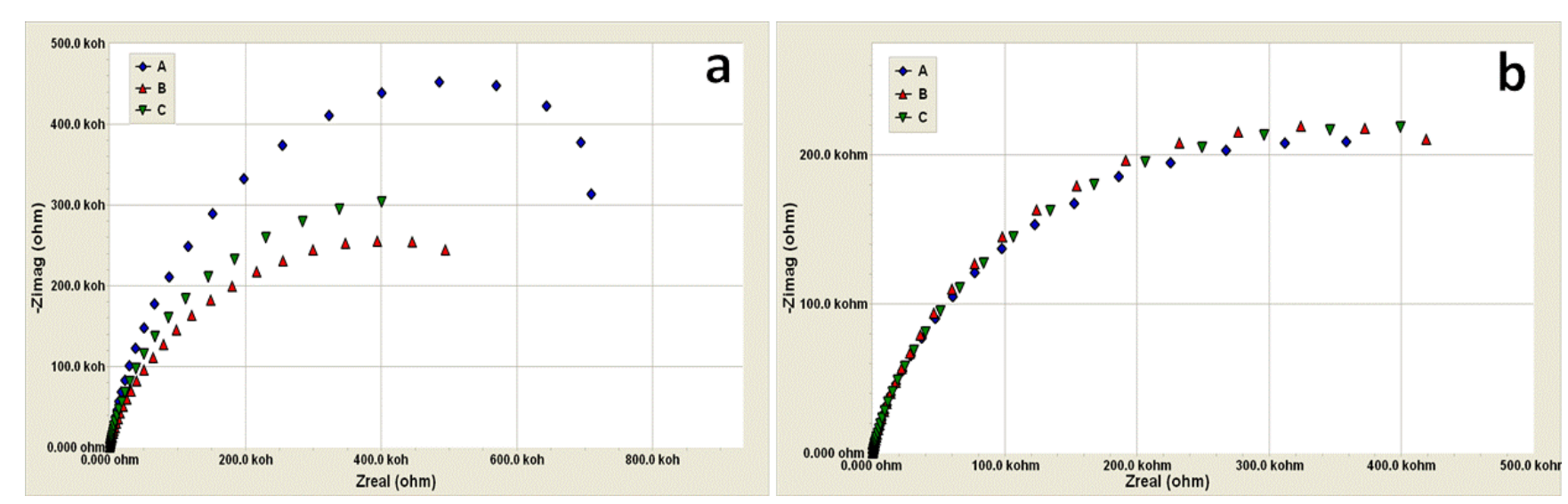

Figure 4. (a) Nyquist plots of Fe in $0.3 \mathrm{M} \mathrm{NaHCO}_{3}+0.1 \mathrm{M} \mathrm{Na}_{2} \mathrm{CO}_{3}$ with smooth surface finish (P1000) (A: $0 \% \mathrm{Na}_{2} \mathrm{MoO}_{4}, \mathrm{~B}: 1 \% \mathrm{Na}_{2} \mathrm{MoO}_{4}, \mathrm{C}: 2 \% \mathrm{Na}_{2} \mathrm{MoO}_{4}$ ). (b) Nyquist plots of Fe in $0.3 \mathrm{M} \mathrm{NaHCO}_{3}+0.1 \mathrm{M} \mathrm{Na}_{2} \mathrm{CO}_{3}$ with rough surface finish (P120) (A: $0 \% \mathrm{Na}_{2} \mathrm{MoO}_{4}, \mathrm{~B}: 1 \%$ $\left.\mathrm{Na}_{2} \mathrm{MoO}_{4}, \mathrm{C}: 2 \% \mathrm{Na}_{2} \mathrm{MoO}_{4}\right)$.

Table 2a. $R_{\mathrm{p}}$ values of $\mathrm{Fe}$ in different solutions in the absence of $\mathrm{Cl}^{-}$ions extrapolated from the $R_{\mathrm{p}} v s . t$ curves.

\begin{tabular}{cc}
\hline Solution & $\boldsymbol{R}_{\boldsymbol{p}}\left(\mathbf{k} \mathbf{\Omega} \mathbf{c m}^{2}\right)$ \\
\hline $0.3 \mathrm{M} \mathrm{NaHCO}_{3}+0.1 \mathrm{M} \mathrm{Na}_{2} \mathrm{CO}_{3}(\mathbf{P 1 0 0 0})$ & $38.8 \pm 19.6$ \\
$0.3 \mathrm{M} \mathrm{NaHCO}_{3}+0.1 \mathrm{M} \mathrm{Na}_{2} \mathrm{CO}_{3}+1 \% \mathrm{Na}_{2} \mathrm{MoO}_{4}(\mathbf{P 1 0 0 0})$ & $22.9 \pm 6.62$ \\
$0.3 \mathrm{M} \mathrm{NaHCO}_{3}+0.1 \mathrm{M} \mathrm{Na}_{2} \mathrm{CO}_{3}+2 \% \mathrm{Na}_{2} \mathrm{MoO}_{4}(\mathbf{P 1 0 0 0})$ & $10.4 \pm 1.60$ \\
$0.3 \mathrm{M} \mathrm{NaHCO}_{3}+0.1 \mathrm{M} \mathrm{Na}_{2} \mathrm{CO}_{3}(\mathbf{P 1 2 0})$ & $17.1 \pm 14.3$ \\
$0.3 \mathrm{M} \mathrm{NaHCO}_{3}+0.1 \mathrm{M} \mathrm{Na}_{2} \mathrm{CO}_{3}+1 \% \mathrm{Na}_{2} \mathrm{MoO}_{4}(\mathbf{P 1 2 0})$ & $11.7 \pm 1.76$ \\
$0.3 \mathrm{M} \mathrm{NaHCO}_{3}+0.1 \mathrm{M} \mathrm{Na}_{2} \mathrm{CO}_{3}+2 \% \mathrm{Na}_{2} \mathrm{MoO}_{4}(\mathbf{P 1 2 0})$ & $15.6 \pm 3.83$ \\
\hline
\end{tabular}

Table $2 \mathbf{b} . R_{\mathrm{p}}$ and $\alpha$ values of $\mathrm{Fe}$ in different solutions in the absence of $\mathrm{Cl}^{-}$ions extrapolated from EIS measurements.

\begin{tabular}{ccc}
\hline Solution & $\boldsymbol{R}_{\boldsymbol{p}}\left(\mathbf{k} \boldsymbol{\Omega} \mathbf{c m}^{2}\right)$ & $\boldsymbol{\alpha}$ \\
\hline $0.3 \mathrm{M} \mathrm{NaHCO}_{3}+0.1 \mathrm{M} \mathrm{Na}_{2} \mathrm{CO}_{3}(\mathbf{P 1 0 0 0})$ & $36.0 \pm 0.598$ & $0.8394 \pm 0.00127$ \\
$0.3 \mathrm{M} \mathrm{NaHCO}_{3}+0.1 \mathrm{M} \mathrm{Na}_{2} \mathrm{CO}_{3}+1 \% \mathrm{Na}_{2} \mathrm{MoO}_{4}(\mathbf{P 1 0 0 0})$ & $20.5 \pm 0.315$ & $0.8167 \pm 0.001253$ \\
$0.3 \mathrm{M} \mathrm{NaHCO}_{3}+0.1 \mathrm{M} \mathrm{Na}_{2} \mathrm{CO}_{3}+2 \% \mathrm{Na}_{2} \mathrm{MoO}_{4}(\mathbf{P 1 0 0 0})$ & $30.1 \pm 1.06$ & $0.802 \pm 0.001335$ \\
$0.3 \mathrm{M} \mathrm{NaHCO}_{3}+0.1 \mathrm{M} \mathrm{Na}_{2} \mathrm{CO}_{3}(\mathbf{P 1 2 0})$ & $17.7 \pm 0.375$ & $0.8136 \pm 0.001358$ \\
$0.3 \mathrm{M} \mathrm{NaHCO}_{3}+0.1 \mathrm{M} \mathrm{Na}_{2} \mathrm{CO}_{3}+1 \% \mathrm{Na}_{2} \mathrm{MoO}_{4}(\mathbf{P 1 2 0})$ & $18.0 \pm 0.318$ & $0.8337 \pm 0.001295$ \\
$0.3 \mathrm{M} \mathrm{NaHCO}_{3}+0.1 \mathrm{M} \mathrm{Na}_{2} \mathrm{CO}_{3}+2 \% \mathrm{Na}_{2} \mathrm{MoO}_{4}(\mathbf{P 1 2 0})$ & $17.6 \pm 0.346$ & $0.8302 \pm 0.001287$ \\
\hline
\end{tabular}




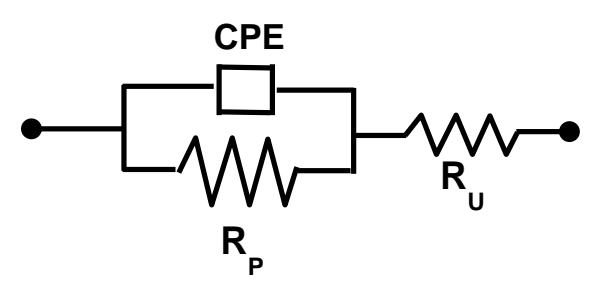

Figure 5. The equivalent circuit used to fit the EIS data. (CPE the constant phase element, $R_{\mathrm{p}}$ the polarization resistance, and the $R_{\mathrm{u}}$ the solution resistance).

CPE is defined by the following equation [24]:

$$
Z(\mathrm{CPE})=Y_{0}^{-1}(\mathrm{j} \omega)^{-\alpha}
$$

in which $Y_{0}$ is the CPE constant, $\omega$ is the angular frequency in $\operatorname{rad~s}^{-1}, \mathrm{j}^{2}=-1$ is the imaginary number, and $\alpha$ is the CPE exponent.

Further inspection of Tables $2 \mathrm{a}$ and $2 \mathrm{~b}$ shows lower $R_{\mathrm{p}}$ values for the rough surfaces when compared to the smooth ones for a given solution. Clearly, the corrosion rate increases with increasing surface roughness. The corrosion current density $\left(i_{\mathrm{c}}\right)$ is expressed by $i_{\mathrm{c}}=B / R_{\mathrm{p}}$ where $B$ is a constant represented by $B=\beta_{\mathrm{a}} \beta_{\mathrm{c}} /\left[2.3\left(\beta_{\mathrm{a}}+\beta_{\mathrm{c}}\right)\right]$ in which $\beta_{\mathrm{a}}$ and $\beta_{\mathrm{c}}$ are the anodic and cathodic Tafel slopes extrapolated from the polarization curves, respectively. The physical meaning of the CPE depends on the value of $\alpha$. CPE represents resistance $(Z[\mathrm{CPE}]=R, \alpha=0)$, capacitance $(Z[\mathrm{CPE}]=C, \alpha=1)$, inductance $(\mathrm{Z}[\mathrm{CPE}]=L$, $\alpha=-1)$, or Warburg impedance for $(\alpha=0.5)$. The CPE is considered a non-ideal capacitor when values of $\alpha$ are $\geq 0.8$. Generally, deviation from an ideal capacitor $(\alpha=1)$ can be attributed to heterogeneity and roughness. Inspection of Table $2 b$ shows $\alpha$ values greater than 0.8 for both smooth and rough samples. As a result, the CPE can be treated as a nonideal capacitor in these solutions.

Figure $6(\mathrm{a}, \mathrm{b})$ shows the potentiodynamic polarization curves for $\mathrm{Fe}$ as a function of $\mathrm{MoO}_{4}^{2-}$ concentration. Figure $6 \mathrm{a}$ represents smooth surface finish while Figure $6 \mathrm{~b}$ represents rough surface finish. Inspection of the curves in Figure 6 shows a passive region above the $E_{\mathrm{c}}$. The presence of $\mathrm{MoO}_{4}^{2-}$ resulted in little effect on the passive current densities. Considering all six curves in Figure 6, the passive current densities range from approximately $13 \mu \mathrm{A} \mathrm{cm}^{-2}$ to $32 \mu \mathrm{A} \mathrm{cm}^{-2}$. Due to such small range, it can be concluded that the presence of $\mathrm{MoO}_{4}^{2-}$ and surface finish (rough vs. smooth) do not affect passivity of $\mathrm{Fe}$ in these solutions. Figure 7 shows SEM images taken after the potentiodynamic polarization experiments. The images show general corrosion only. 

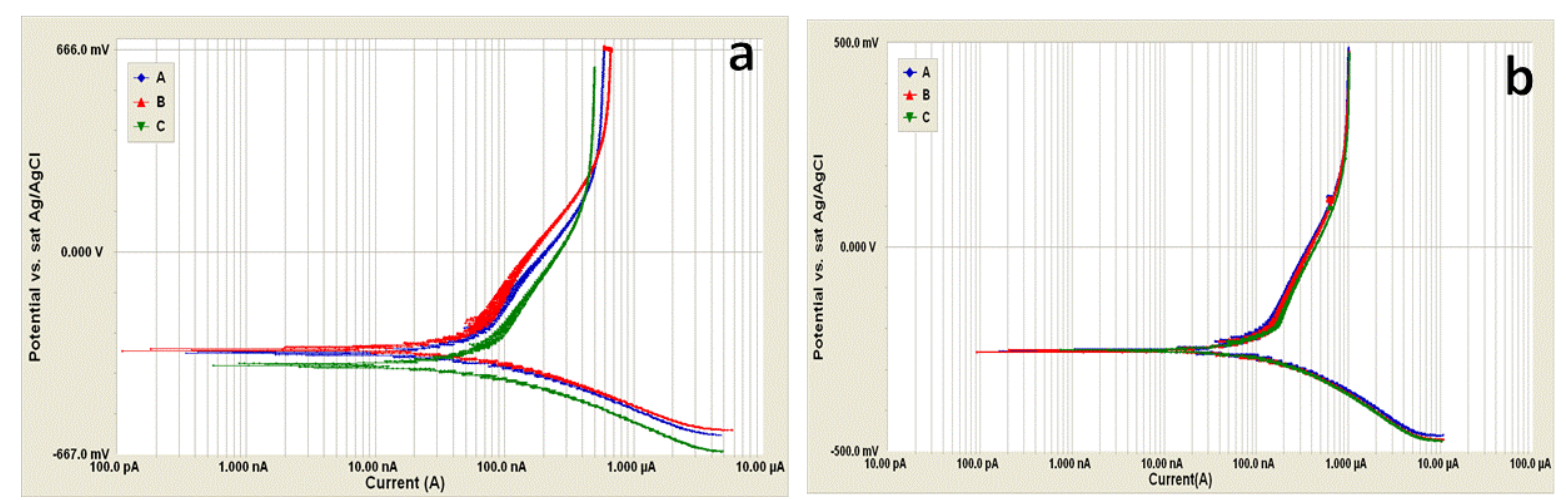

Figure 6. (a) Potentiodynamic polarization curves of Fe in $0.3 \mathrm{M} \mathrm{NaHCO}_{3}+0.1 \mathrm{M} \mathrm{Na}_{2} \mathrm{CO}_{3}$ with smooth surface finish (P1000) (A: $0 \% \mathrm{Na}_{2} \mathrm{MoO}_{4}, \mathrm{~B}: 1 \% \mathrm{Na}_{2} \mathrm{MoO}_{4}, \mathrm{C}: 2 \% \mathrm{Na}_{2} \mathrm{MoO}_{4}$ ). (b) Potentiodynamic polarization curves of $\mathrm{Fe}$ in $0.3 \mathrm{M} \mathrm{NaHCO}_{3}+0.1 \mathrm{M} \mathrm{Na}_{2} \mathrm{CO}_{3}$ with rough surface finish (P120) (A: $\left.0 \% \mathrm{Na}_{2} \mathrm{MoO}_{4}, \mathrm{~B}: 1 \% \mathrm{Na}_{2} \mathrm{MoO}_{4}, \mathrm{C}: 2 \% \mathrm{Na}_{2} \mathrm{MoO}_{4}\right)$.
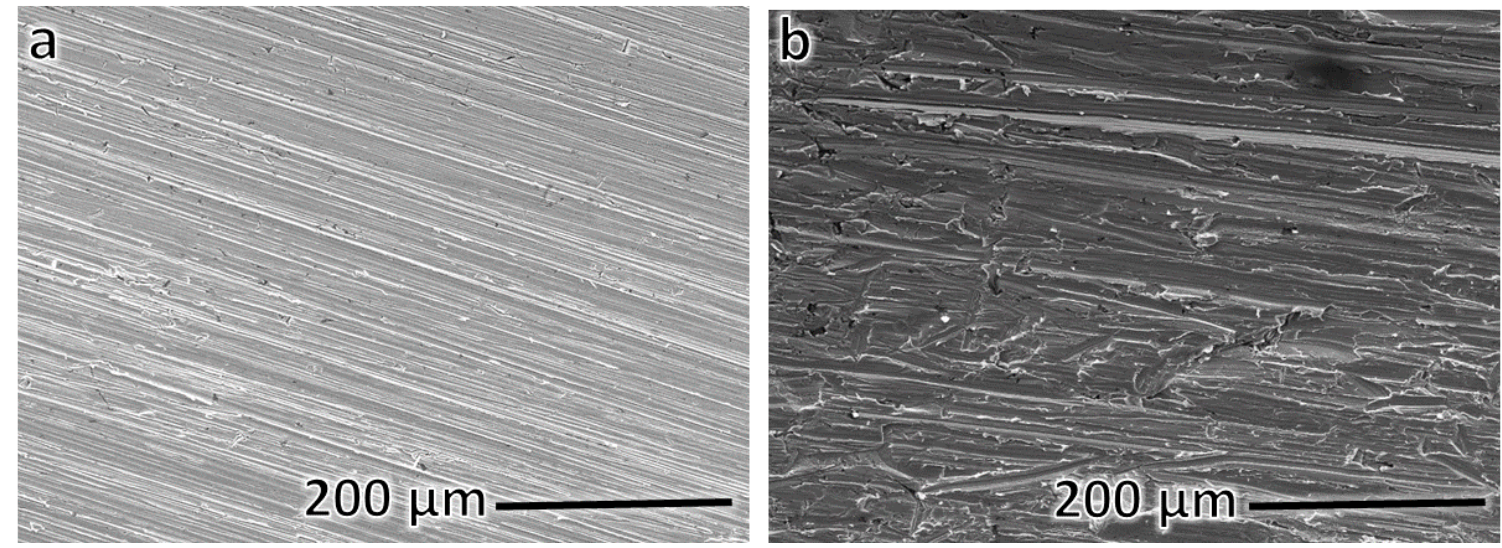

Figure 7. (a) SEM of Fe after potentiodynamic polarization in $0.3 \mathrm{M} \mathrm{NaHCO}_{3}+0.1 \mathrm{M}$ $\mathrm{Na}_{2} \mathrm{CO}_{3}$ (smooth surface finish P1000). (b): SEM of Fe after potentiodynamic polarization in $0.3 \mathrm{M} \mathrm{NaHCO}_{3}+0.1 \mathrm{M} \mathrm{Na}_{2} \mathrm{CO}_{3}$ (rough surface finish P120).

\subsection{The corrosion behavior of $\mathrm{Fe}$ in the presence of $\mathrm{Cl}^{-}$ions}
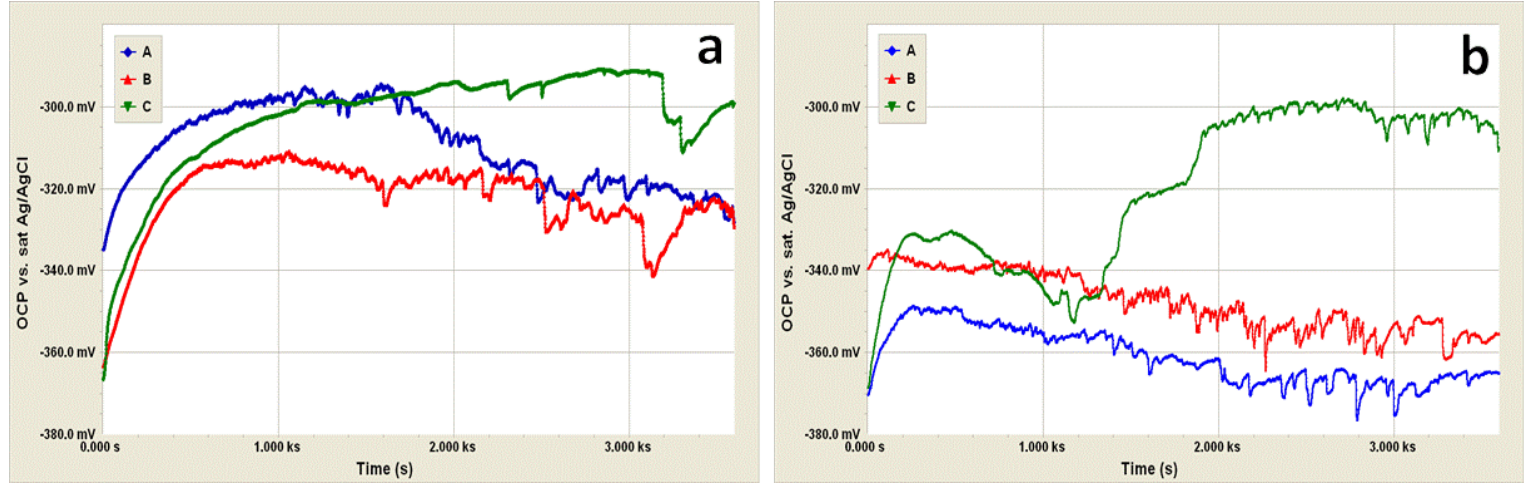

Figure 8. (a) OCP $v$ s. $t$ of $\mathrm{Fe}$ in $0.3 \mathrm{M} \mathrm{NaHCO}_{3}+0.1 \mathrm{M} \mathrm{Na}_{2} \mathrm{CO}_{3}+1 \% \mathrm{NaCl}$ with smooth surface finish (P1000) (A: $0 \% \mathrm{Na}_{2} \mathrm{MoO}_{4}, \mathrm{~B}: 1 \% \mathrm{Na}_{2} \mathrm{MoO}_{4}, \mathrm{C}: 2 \% \mathrm{Na}_{2} \mathrm{MoO}_{4}$ ). (b): OCP vs. $t$ of $\mathrm{Fe}$ in $0.3 \mathrm{M} \mathrm{NaHCO}_{3}+0.1 \mathrm{M} \mathrm{Na}_{2} \mathrm{CO}_{3}+1 \% \mathrm{NaCl}$ with rough surface finish (P120) (A: $0 \%$ $\left.\mathrm{Na}_{2} \mathrm{MoO}_{4}, \mathrm{~B}: 1 \% \mathrm{Na}_{2} \mathrm{MoO}_{4}, \mathrm{C}: 2 \% \mathrm{Na}_{2} \mathrm{MoO}_{4}\right)$. 

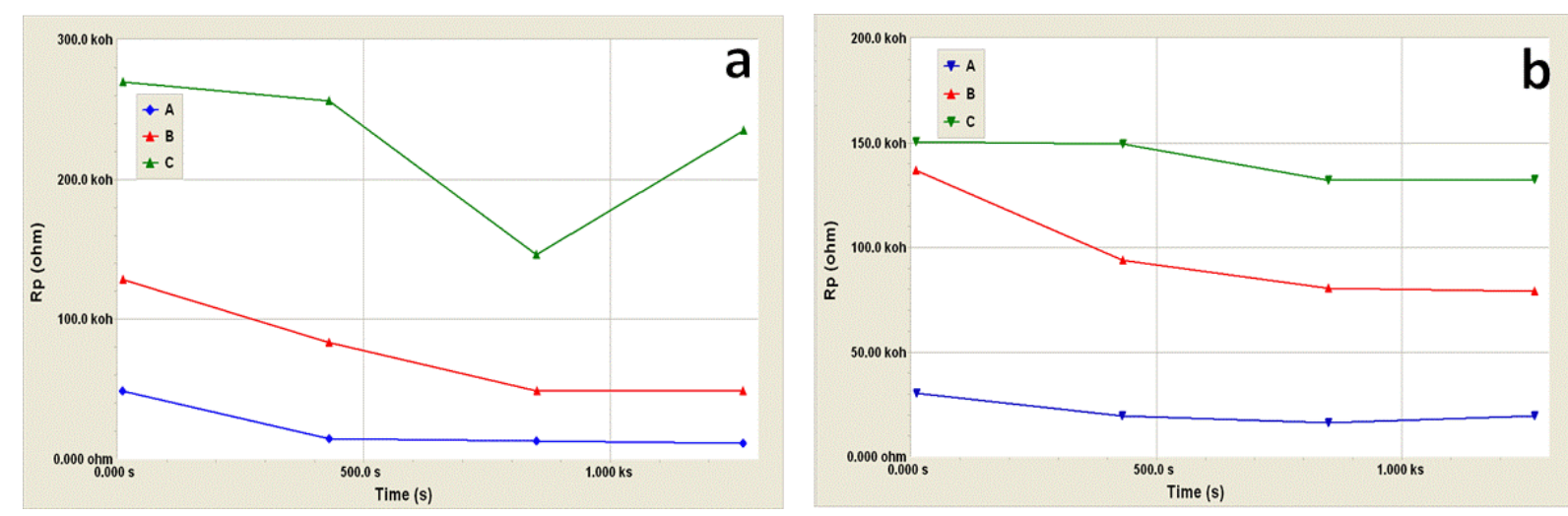

Figure 9. (a): $\mathrm{R}_{\mathrm{p}} v$ s. $t$ of $\mathrm{Fe}$ in $0.3 \mathrm{M} \mathrm{NaHCO}_{3}+0.1 \mathrm{M} \mathrm{Na}_{2} \mathrm{CO}_{3}+1 \% \mathrm{NaCl}$ with smooth surface finish (P1000) (A: $0 \% \mathrm{Na}_{2} \mathrm{MoO}_{4}, \mathrm{~B}: 1 \% \mathrm{Na}_{2} \mathrm{MoO}_{4}, \mathrm{C}: 2 \% \mathrm{Na}_{2} \mathrm{MoO}_{4}$ ). (b) $\mathrm{R}_{\mathrm{p}} v$ s. $t$ of Fe in $0.3 \mathrm{M} \mathrm{NaHCO}_{3}+0.1 \mathrm{M} \mathrm{Na}_{2} \mathrm{CO}_{3}+1 \% \mathrm{NaCl}$ with rough surface finish (P120) (A: $0 \%$ $\left.\mathrm{Na}_{2} \mathrm{MoO}_{4}, \mathrm{~B}: 1 \% \mathrm{Na}_{2} \mathrm{MoO}_{4}, \mathrm{C}: 2 \% \mathrm{Na}_{2} \mathrm{MoO}_{4}\right)$.
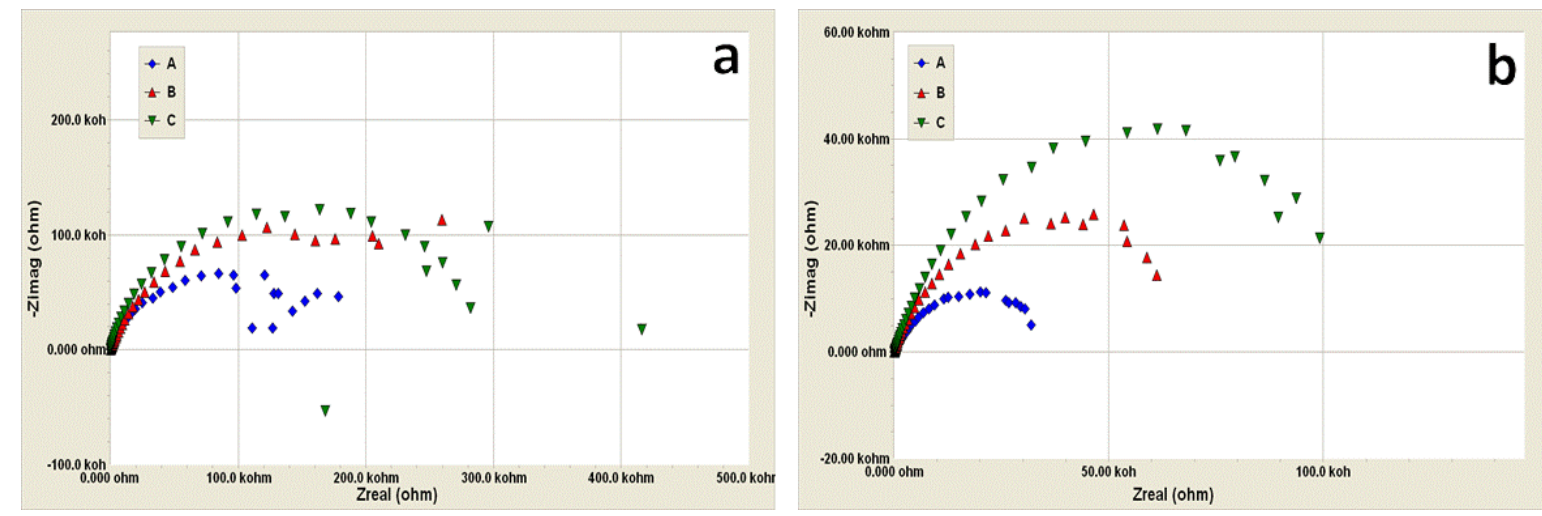

Figure 10. (a) Nyquist plots of $\mathrm{Fe}$ in $0.3 \mathrm{M} \mathrm{NaHCO}_{3}+0.1 \mathrm{M} \mathrm{Na}_{2} \mathrm{CO}_{3}+1 \% \mathrm{NaCl}$ with smooth surface finish (P1000) (A: $0 \% \mathrm{Na}_{2} \mathrm{MoO}_{4}, \mathrm{~B}: 1 \% \mathrm{Na}_{2} \mathrm{MoO}_{4}, \mathrm{C}: 2 \% \mathrm{Na}_{2} \mathrm{MoO}_{4}$ ). (b): Nyquist plots of $\mathrm{Fe}$ in $0.3 \mathrm{M} \mathrm{NaHCO}_{3}+0.1 \mathrm{M} \mathrm{Na}_{2} \mathrm{CO}_{3}+1 \% \mathrm{NaCl}$ with rough surface finish (P120) (A: $\left.0 \% \mathrm{Na}_{2} \mathrm{MoO}_{4}, \mathrm{~B}: 1 \% \mathrm{Na}_{2} \mathrm{MoO}_{4}, \mathrm{C}: 2 \% \mathrm{Na}_{2} \mathrm{MoO}_{4}\right)$.

Figure 8(a,b) shows the OCP vs. $t$ for Fe tested in $0.3 \mathrm{M} \mathrm{NaHCO}_{3}+0.1 \mathrm{M} \mathrm{Na}_{2} \mathrm{CO}_{3}+$ $1 \% \mathrm{NaCl}$ as a function of $\mathrm{MoO}_{4}^{2-}$ and surface roughness. Figure $8 \mathrm{a}$ represents smooth surface finish (P1000) while Figure 8b represents rough surface finish (P120). Inspections of Figures $8 \mathrm{a}$ and $8 \mathrm{~b}$, the OCP gradually increases before reaching a plateau after few minutes from immersion. Then, the OCP starts to fluctuate combined with an overall decrease in the OCP with time. The latter behavior is especially valid for curves A $(0 \%$ $\left.\mathrm{MoO}_{4}^{2-}\right)$ and $\mathrm{B}\left(1 \% \mathrm{MoO}_{4}^{2-}\right)$. Curves $\mathrm{C}\left(2 \% \mathrm{MoO}_{4}^{2-}\right)$ show less fluctuations in comparison to curves $\mathrm{A}$ and $\mathrm{B}$ combined with a slight overall increase of the $\mathrm{OCP}$ with time. The initial increase in the OCP with time can be attributed to the transformation of the preexisting film to a stable film. However, due to $\mathrm{Cl}^{-}$attack, the film becomes less stable with the possibility of metastable pits formation as indicated by the OCP fluctuations and its small overall decrease with time. Curves $\mathrm{C}$ show less fluctuations, especially for the smooth surface finish samples. The presence of $2 \% \mathrm{MoO}_{4}^{2-}$ (curve C) enhances Fe resistance to 
corrosion. Figure 9(a,b) shows $R_{\mathrm{p}}$ values $v s$. $t$ curves with the average $R_{\mathrm{p}}$ values reported in Table 3a. Figure 10(a,b) shows the Nyquist plots for the smooth and rough surfaces, respectively. $R_{\mathrm{p}}$ and $\alpha$ values (Table $3 \mathrm{~b}$ ) were obtained by fitting the equivalent electrical circuit (Figure 5) to the impedance data from the EIS measurements. The $R_{\mathrm{p}}$ values extrapolated from the EIS curves and reported in Table $3 \mathrm{~b}$ follow the same trend of the $R_{\mathrm{p}}$ values extrapolated from $R_{\mathrm{p}} v$ s. $t$ curves and reported in Table $3 \mathrm{a}$. Examining the $R_{\mathrm{p}}$ values in Tables 2(a,b) and Tables 3(a,b) reveals the following:

1. The $R_{\mathrm{p}}$ values in the presence of $\mathrm{Cl}^{-}$are lower than the $R_{\mathrm{p}}$ values in the absence of $\mathrm{Cl}^{-}$ for a given solution and surface roughness.

2. In the presence of $\mathrm{Cl}^{-}$, the smooth surface finish samples have higher $R_{\mathrm{p}}$ values than the rough finish samples.

3. In the presence of $\mathrm{Cl}^{-}$, the $R_{\mathrm{p}}$ values increase with increasing $\mathrm{MoO}_{4}^{2-}$ concentration.

Table 3a. $R_{\mathrm{p}}$ values of $\mathrm{Fe}$ in different solutions in the presence of $1 \% \mathrm{NaCl}$ extrapolated from the $R_{\mathrm{p}} v s . t$ curves.

\begin{tabular}{cc}
\hline Solution & $\boldsymbol{R}_{\mathbf{p}}\left(\mathbf{k} \boldsymbol{\Omega} \mathbf{c m}^{2}\right)$ \\
\hline $0.3 \mathrm{M} \mathrm{NaHCO}_{3}+0.1 \mathrm{M} \mathrm{Na}_{2} \mathrm{CO}_{3}+1 \% \mathrm{NaCl}(\mathbf{P 1 0 0 0})$ & $0.683 \pm 0.486$ \\
$0.3 \mathrm{M} \mathrm{NaHCO}_{3}+0.1 \mathrm{M} \mathrm{Na}_{2} \mathrm{CO}_{3}+1 \% \mathrm{NaCl}+1 \% \mathrm{Na}_{2} \mathrm{MoO}_{4}(\mathbf{P 1 0 0 0})$ & $2.43 \pm 1.02$ \\
$0.3 \mathrm{M} \mathrm{NaHCO}_{3}+0.1 \mathrm{M} \mathrm{Na}_{2} \mathrm{CO}_{3}+1 \% \mathrm{NaCl}+2 \% \mathrm{Na}_{2} \mathrm{MoO}_{4}(\mathbf{P 1 0 0 0})$ & $7.12 \pm 1.51$ \\
$0.3 \mathrm{M} \mathrm{NaHCO}_{3}+0.1 \mathrm{M} \mathrm{Na}_{2} \mathrm{CO}_{3}+1 \% \mathrm{NaCl}(\mathbf{P 1 2 0})$ & $0.673 \pm 0.169$ \\
$0.3 \mathrm{M} \mathrm{NaHCO}_{3}+0.1 \mathrm{M} \mathrm{Na}_{2} \mathrm{CO}_{3}+1 \% \mathrm{NaCl}+1 \% \mathrm{Na}_{2} \mathrm{MoO}_{4}(\mathbf{P 1 2 0})$ & $3.06 \pm 0.735$ \\
$0.3 \mathrm{M} \mathrm{NaHCO}_{3}+0.1 \mathrm{M} \mathrm{Na}_{2} \mathrm{CO}_{3}+1 \% \mathrm{NaCl}+2 \% \mathrm{Na}_{2} \mathrm{MoO}_{4}(\mathbf{P 1 2 0})$ & $4.43 \pm 0.278$ \\
\hline
\end{tabular}

Table $3 \mathbf{b} . R_{\mathrm{p}}$ and $\alpha$ values of $\mathrm{Fe}$ in different solutions in the presence of $1 \% \mathrm{NaCl}$ extrapolated from EIS measurements.

\begin{tabular}{ccc}
\hline Solution & $\boldsymbol{R}_{\mathbf{p}}\left(\mathbf{k} \mathbf{\Omega} \mathbf{c m}^{2}\right)$ & $\boldsymbol{\alpha}$ \\
\hline $0.3 \mathrm{M} \mathrm{NaHCO}_{3}+0.1 \mathrm{M} \mathrm{Na}_{2} \mathrm{CO}_{3}+1 \% \mathrm{NaCl}(\mathbf{P 1 0 0 0})$ & $4.89 \pm 0.0435$ & $0.8365 \pm 0.001513$ \\
$0.3 \mathrm{M} \mathrm{NaHCO}_{3}+0.1 \mathrm{M} \mathrm{Na}_{2} \mathrm{CO}_{3}+1 \% \mathrm{NaCl}+1 \%$ & $9.73 \pm 0.149$ & $0.7856 \pm 0.001318$ \\
$\mathrm{Na}_{2} \mathrm{MoO}_{4}(\mathbf{P 1 0 0 0})$ & & \\
$\quad 0.3 \mathrm{M} \mathrm{NaHCO}_{3}+0.1 \mathrm{M} \mathrm{Na}_{2} \mathrm{CO}_{3}+1 \% \mathrm{NaCl}+2 \%$ & $8.37 \pm .07056$ & $0.9005 \pm 0.001417$ \\
$\mathrm{Na}_{2} \mathrm{MoO}_{4}(\mathbf{P 1 0 0 0})$ & & \\
$0.3 \mathrm{M} \mathrm{NaHCO}_{3}+0.1 \mathrm{M} \mathrm{Na}_{2} \mathrm{CO}_{3}+1 \% \mathrm{NaCl}(\mathbf{P 1 2 0})$ & $1.15 \pm 0.01551$ & $0.6951 \pm 0.001675$ \\
$0.3 \mathrm{M} \mathrm{NaHCO}_{3}+0.1 \mathrm{M} \mathrm{Na}_{2} \mathrm{CO}_{3}+1 \% \mathrm{NaCl}+1 \%$ & $2.38 \pm 0.03162$ & $0.7426 \pm 0.001563$ \\
$\mathrm{Na}_{2} \mathrm{MoO}_{4}(\mathbf{P 1 2 0})$ & & \\
$0.3 \mathrm{M} \mathrm{NaHCO}_{3}+0.1 \mathrm{M} \mathrm{Na}_{2} \mathrm{CO}_{3}+1 \% \mathrm{NaCl}+2 \%$ & $3.71 \pm 0.04581$ & $0.7638 \pm 0.00143$ \\
$\mathrm{Na}_{2} \mathrm{MoO}_{4}(\mathbf{P 1 2 0})$ & & \\
\hline
\end{tabular}


Clearly, while the presence of $\mathrm{Cl}^{-}$ions increased the corrosion rate of $\mathrm{Fe}$, the addition of $\mathrm{MoO}_{4}^{2-}$ enhanced the corrosion resistance of $\mathrm{Fe}$ in bicarbonate/carbonate solutions containing $\mathrm{Cl}^{-}$. Inspection of the $\alpha$ values reported in Table $3 \mathrm{~b}$ shows a range from 0.6951 to 0.9005 . Moreover, the lowest $\alpha$ values were obtained for the rough surfaces. $\mathrm{Cl}^{-}$is known to induce localized (pitting) corrosion. The lowest reported value for all solutions $(\alpha=0.6951)$ is obtained for a rough surface in the presence of $\mathrm{Cl}^{-}$and in the absence of $\mathrm{MoO}_{4}^{2-}$. Pitting corrosion is expected to occur under these conditions. As a result, $\mathrm{CPE}$ cannot be treated as a capacitor.

Figure 11(a,b) shows the potentiodynamic polarization curves for $\mathrm{Fe}$ in $0.3 \mathrm{M}$ $\mathrm{NaHCO}_{3}+0.1 \mathrm{M} \mathrm{Na}_{2} \mathrm{CO}_{3}+1 \% \mathrm{NaCl}$ as a function of $\mathrm{MoO}_{4}^{2-}$ and surface roughness. Comparing curves A in Figure 11 (presence of $\mathrm{Cl}^{-}$) to curves A in Figure 6 (absence of $\mathrm{Cl}^{-}$) shows that the presence of $\mathrm{Cl}^{-}$resulted in passivity breakdown at about $-200 \mathrm{mV}$ (pitting potential). Comparing curve A in Figure 11a (smooth) to curve A in Figure 11b (rough) reveals the rough surface resulted in smaller passive potential range in comparison to the smooth surface. The presence of $\mathrm{MoO}_{4}^{2-}$ resulted in increasing the passive potential range, lower passive current densities, and higher pitting potentials as seen in curves B and C in Figure 11. Figure 12 shows SEM images of Fe surfaces under different conditions. Figures 12(a) and 12(b) show Fe with rough surface finish after one hour of immersion (at OCP) in $0.3 \mathrm{M} \mathrm{NaHCO}_{3}+0.1 \mathrm{M} \mathrm{Na}_{2} \mathrm{CO}_{3}+1 \% \mathrm{NaCl}$ in the absence and presence of $2 \% \mathrm{Na}_{2} \mathrm{MoO}_{4}$, respectively. Figures 12(c) and 12(d) show Fe with rough surface finish after 72 hours of immersion. The images show general corrosion only with no signs of pitting corrosion. Figures 12(e) and 12(f) show SEM images of Fe in $0.3 \mathrm{M} \mathrm{NaHCO}_{3}+0.1 \mathrm{M} \mathrm{Na}_{2} \mathrm{CO}_{3}+1 \%$ $\mathrm{NaCl}$ in the absence of $\mathrm{MoO}_{4}^{2-}$. Figures 12(g) and 12(h) show SEM images of $\mathrm{Fe}$ in $0.3 \mathrm{M}$ $\mathrm{NaHCO}_{3}+0.1 \mathrm{M} \mathrm{Na}_{2} \mathrm{CO}_{3}+1 \% \mathrm{NaCl}$ in the presence of $1 \% \mathrm{MoO}_{4}^{2-}$. Figures 12(i) and 12(j) show SEM images of Fe in $0.3 \mathrm{M} \mathrm{NaHCO}_{3}+0.1 \mathrm{M} \mathrm{Na}_{2} \mathrm{CO}_{3}+1 \% \mathrm{NaCl}$ in the presence of $2 \% \mathrm{MoO}_{4}^{2-}$. The SEM images were taken after the potentiodynamic polarization experiments. While the presence of $1 \% \mathrm{NaCl}$ resulted in pitting corrosion in the absence of $\mathrm{MoO}_{4}^{2-}$ and in the presence of $1 \% \mathrm{MoO}_{4}^{2-}$, the presence of $2 \% \mathrm{MoO}_{4}^{2-}$ inhibited pitting corrosion. Based on the potentiodynamic polarization experiments and SEM images, the presence of sufficient concentration of $\mathrm{MoO}_{4}^{2-}$ enhances the pitting corrosion resistance of $\mathrm{Fe}$ in the presence of $\mathrm{Cl}^{-}$by increasing the pitting potential and decreasing the passive current densities. 

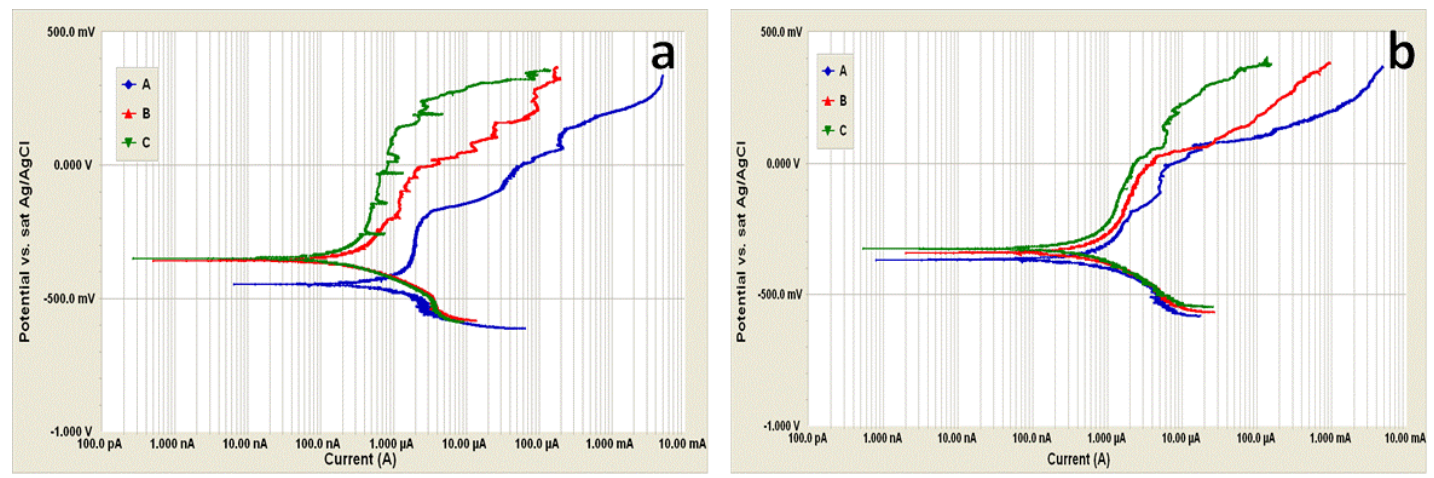

Figure 11. (a) Potentiodynamic polarization curves of Fe in $0.3 \mathrm{M} \mathrm{NaHCO}_{3}+0.1 \mathrm{M} \mathrm{Na}_{2} \mathrm{CO}_{3}+1 \%$ $\mathrm{NaCl}$ with smooth surface finish (P1000) (A: $0 \% \mathrm{Na}_{2} \mathrm{MoO}_{4}, \mathrm{~B}: 1 \% \mathrm{Na}_{2} \mathrm{MoO}_{4}, \mathrm{C}: 2 \% \mathrm{Na}_{2} \mathrm{MoO}_{4}$ ). (b) Potentiodynamic polarization curves of $\mathrm{Fe}$ in $0.3 \mathrm{M} \mathrm{NaHCO}_{3}+0.1 \mathrm{M} \mathrm{Na}_{2} \mathrm{CO}_{3}+1 \% \mathrm{NaCl}$ with rough surface finish (P120) (A: $\left.0 \% \mathrm{Na}_{2} \mathrm{MoO}_{4}, \mathrm{~B}: 1 \% \mathrm{Na}_{2} \mathrm{MoO}_{4}, \mathrm{C}: 2 \% \mathrm{Na}_{2} \mathrm{MoO}_{4}\right)$.
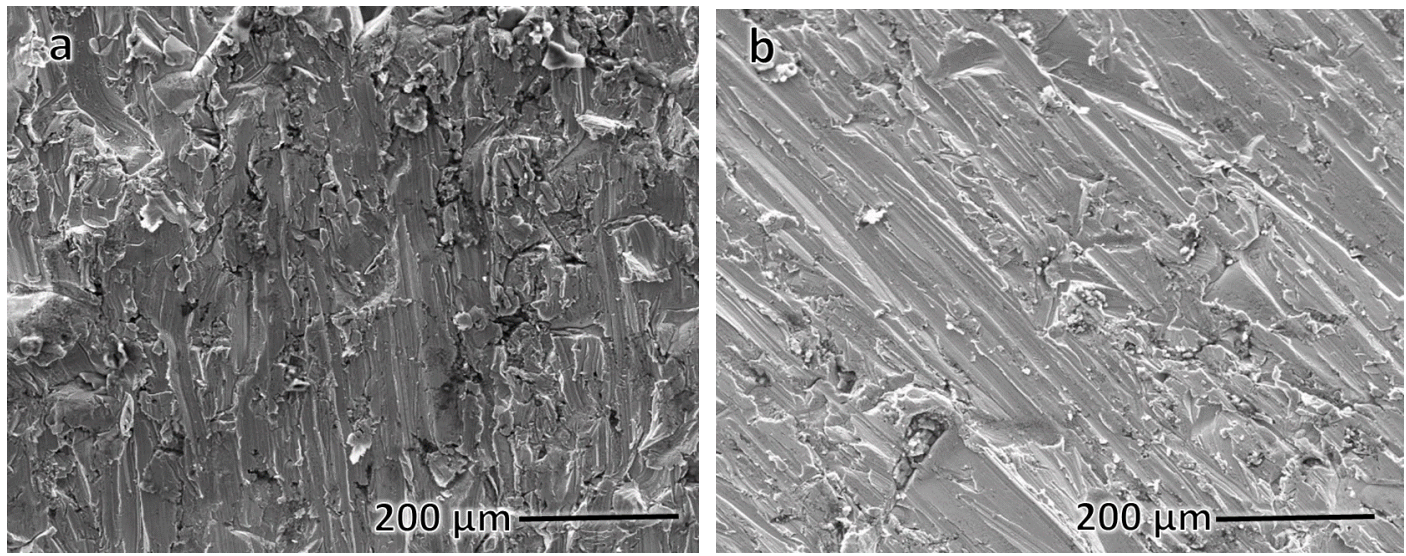

Figure 12. (a): SEM of Fe after one hour of immersion in $0.3 \mathrm{M} \mathrm{NaHCO}_{3}+0.1 \mathrm{M} \mathrm{Na}_{2} \mathrm{CO}_{3}+1 \%$ $\mathrm{NaCl}$ (rough surface finish P120). (b): SEM of Fe after one hour of immersion at the OCP in $0.3 \mathrm{M}$ $\mathrm{NaHCO}_{3}+0.1 \mathrm{M} \mathrm{Na}_{2} \mathrm{CO}_{3}+1 \% \mathrm{NaCl}+2 \% \mathrm{Na}_{2} \mathrm{MoO}_{4}$ (rough surface finish $\mathrm{P} 120$ ).
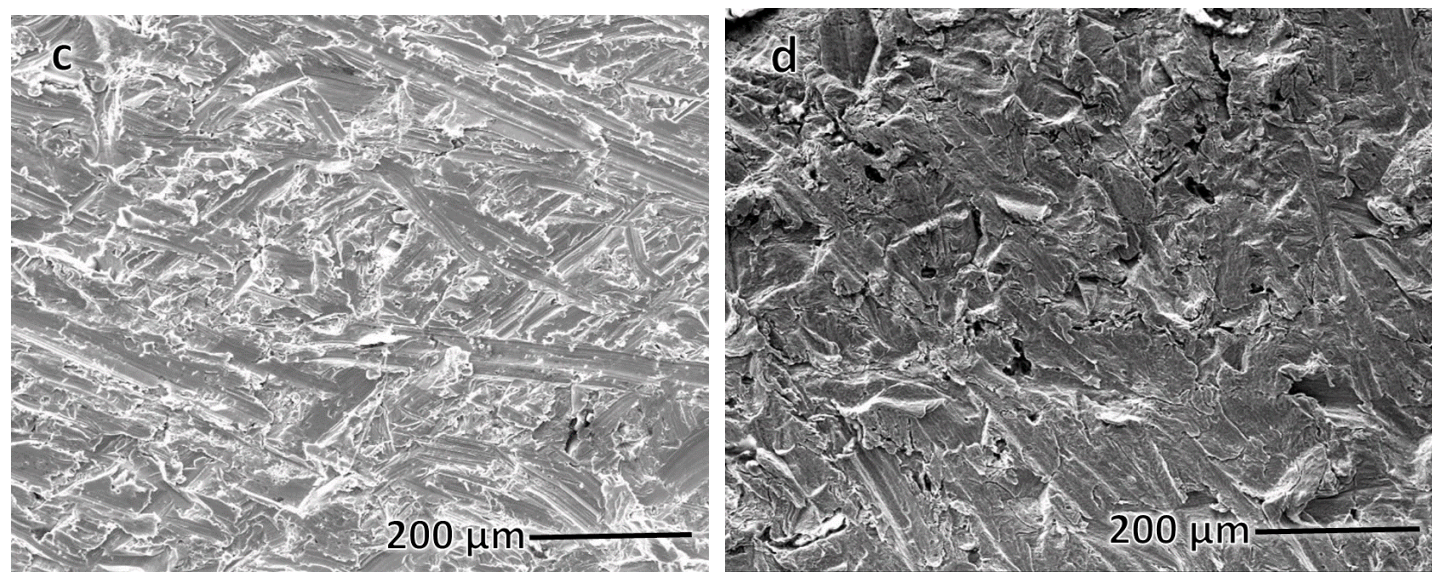

Figure 12. (c): SEM of Fe after 72 hours of immersion in $0.3 \mathrm{M} \mathrm{NaHCO}_{3}+0.1 \mathrm{M} \mathrm{Na}_{2} \mathrm{CO}_{3}+1 \% \mathrm{NaCl}$ (rough surface finish P120). (d): SEM of Fe after 72 hours of immersion at the OCP in $0.3 \mathrm{M} \mathrm{NaHCO}_{3}$ $+0.1 \mathrm{M} \mathrm{Na}_{2} \mathrm{CO}_{3}+1 \% \mathrm{NaCl}+2 \% \mathrm{Na}_{2} \mathrm{MoO}_{4}$ (rough surface finish P120). 

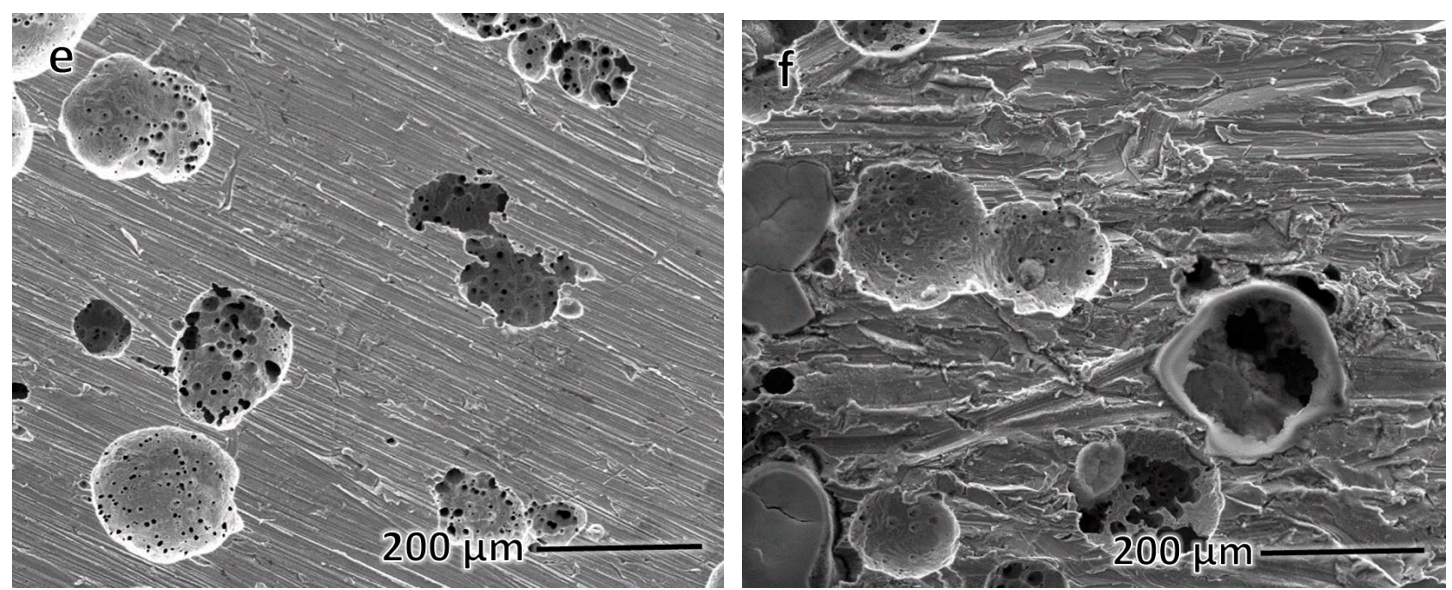

Figure 12. (e): $\mathrm{SEM}$ of $\mathrm{Fe}$ after potentiodynamic polarization in $0.3 \mathrm{M} \mathrm{NaHCO}_{3}+0.1 \mathrm{M} \mathrm{Na}_{2} \mathrm{CO}_{3}+1 \%$ $\mathrm{NaCl}$ (smooth surface finish P1000). (f): SEM of Fe after potentiodynamic polarization in $0.3 \mathrm{M}$ $\mathrm{NaHCO}_{3}+0.1 \mathrm{M} \mathrm{Na}_{2} \mathrm{CO}_{3}+1 \% \mathrm{NaCl}$ (rough surface finish P120)
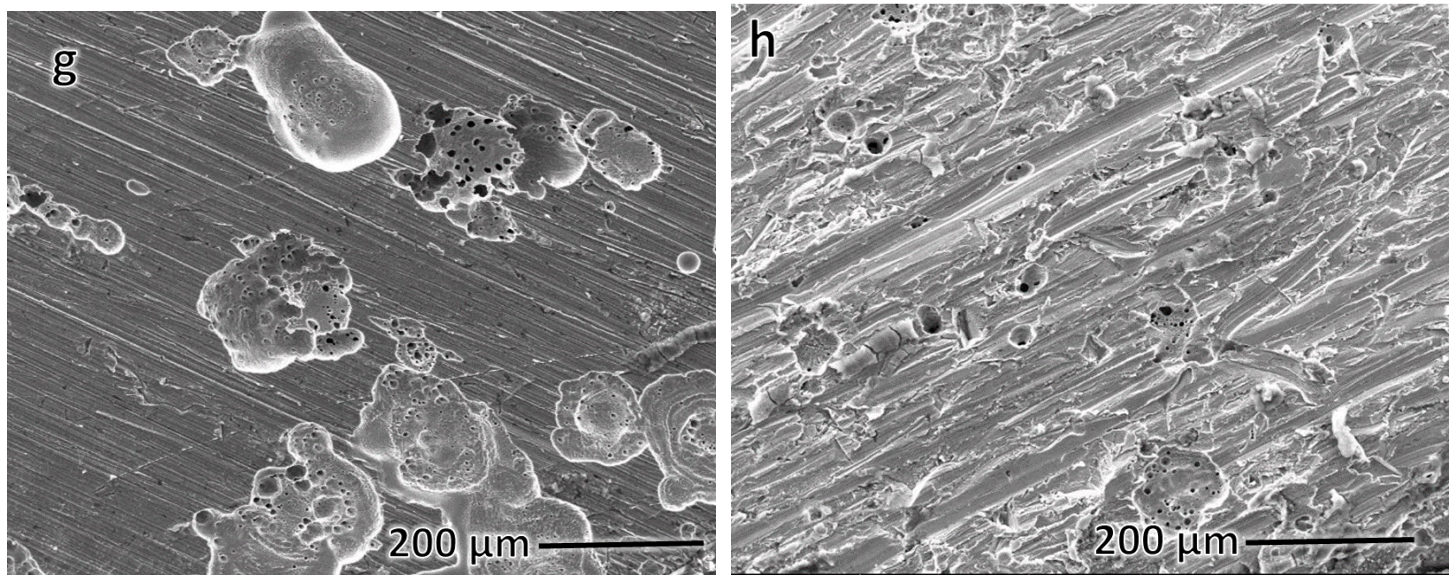

Figure 12. (g): SEM of Fe after potentiodynamic polarization in $0.3 \mathrm{M} \mathrm{NaHCO}_{3}+0.1 \mathrm{M} \mathrm{Na}_{2} \mathrm{CO}_{3}+1 \%$ $\mathrm{NaCl}+1 \% \mathrm{Na}_{2} \mathrm{MoO}_{4}$ (smooth surface finish P1000). (h): SEM of Fe after potentiodynamic polarization in $0.3 \mathrm{M} \mathrm{NaHCO}_{3}+0.1 \mathrm{M} \mathrm{Na}_{2} \mathrm{CO}_{3}+1 \% \mathrm{NaCl}+1 \% \mathrm{Na}_{2} \mathrm{MoO}_{4}$ (rough surface finish $\mathrm{P} 120$ ).
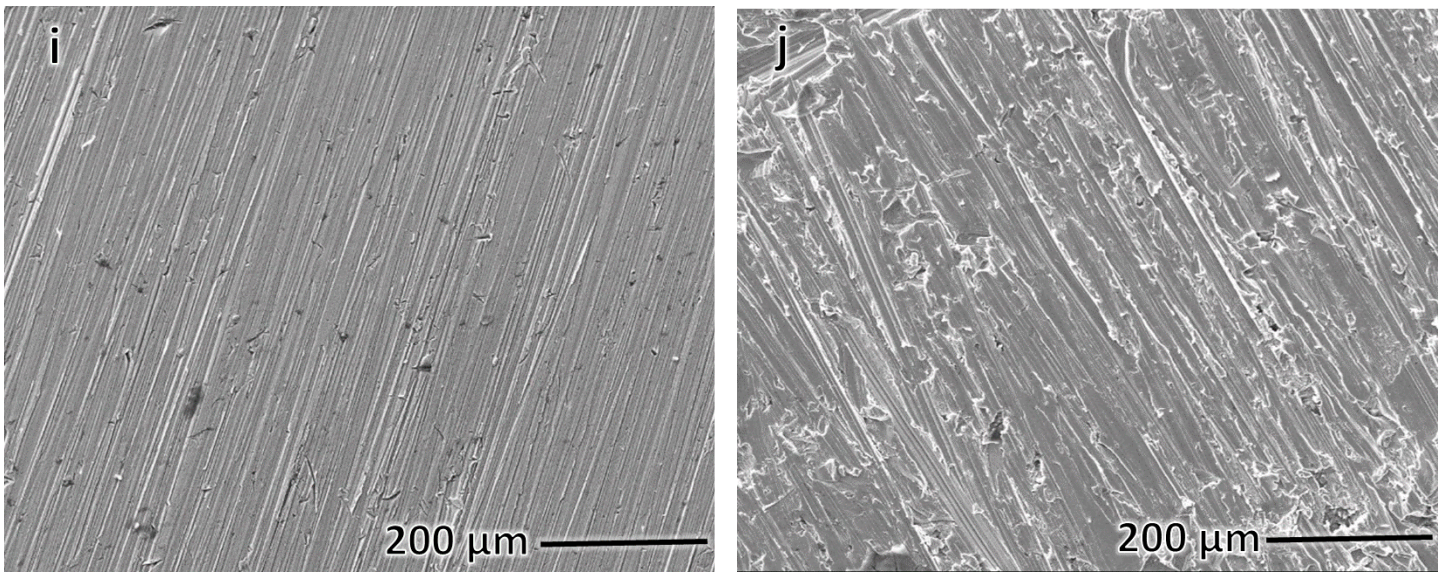

Figure 12. (i): $\mathrm{SEM}$ of $\mathrm{Fe}$ after potentiodynamic polarization in $0.3 \mathrm{M} \mathrm{NaHCO}_{3}+0.1 \mathrm{M} \mathrm{Na}_{2} \mathrm{CO}_{3}+1 \%$ $\mathrm{NaCl}+2 \% \mathrm{Na}_{2} \mathrm{MoO}_{4}$ (smooth surface finish P1000). (j): SEM of Fe after potentiodynamic polarization in $0.3 \mathrm{M} \mathrm{NaHCO}_{3}+0.1 \mathrm{M} \mathrm{Na}_{2} \mathrm{CO}_{3}+1 \% \mathrm{NaCl}+2 \% \mathrm{Na}_{2} \mathrm{MoO}_{4}$ (rough surface finish P120). 


\section{Conclusions}

\subsection{In the absence of $\mathrm{Cl}^{-}$:}

1. The presence of $\mathrm{MoO}_{4}^{2-}$ does not enhance the corrosion resistance of $\mathrm{Fe}$ in $0.3 \mathrm{M}$ $\mathrm{NaHCO}_{3}+0.1 \mathrm{M} \mathrm{Na}_{2} \mathrm{CO}_{3}$. Interestingly, small concentrations of $\mathrm{MoO}_{4}^{2-}$ might decrease the corrosion resistance. This is true for smooth and rough surface finishes.

2. $\mathrm{MoO}_{4}^{2-}$ and surface finish do not affect passivity of Fe in $0.3 \mathrm{M} \mathrm{NaHCO}_{3}+0.1 \mathrm{M}$ $\mathrm{Na}_{2} \mathrm{CO}_{3}$.

3. The CPE can be treated as a non-ideal capacitor in $0.3 \mathrm{M} \mathrm{NaHCO}_{3}+0.1 \mathrm{M} \mathrm{Na}_{2} \mathrm{CO}_{3}$ in the absence and presence of $\mathrm{MoO}_{4}^{2-}$. This is true for smooth and rough surface finishes.

\subsection{In the presence of $\mathrm{Cl}^{-}$ions:}

1. The presence of $\mathrm{Cl}^{-}$increases the corrosion rate of $\mathrm{Fe}$ in $0.3 \mathrm{M} \mathrm{NaHCO}_{3}+0.1 \mathrm{M}$ $\mathrm{Na}_{2} \mathrm{CO}_{3}$.

2. The smooth finish surfaces have lower corrosion rates than the rough finish surfaces for a given solution.

3. The corrosion rate decreases with increasing $\mathrm{MoO}_{4}^{2-}$ concentration.

4. The CPE can be treated as a non-ideal capacitor in $0.3 \mathrm{M} \mathrm{NaHCO}_{3}+0.1 \mathrm{M} \mathrm{Na}_{2} \mathrm{CO}_{3}+$ $1 \% \mathrm{NaCl}$ in the absence and presence of $\mathrm{MoO}_{4}^{2-}$ for the relatively smooth finish surface but not the relatively rough surface finish where $\alpha$ is less than 0.80 .

5. The presence of $\mathrm{MoO}_{4}^{2-}$ enhances the pitting corrosion resistance of $\mathrm{Fe}$ in $0.3 \mathrm{M}$ $\mathrm{NaHCO}_{3}+0.1 \mathrm{M} \mathrm{Na}_{2} \mathrm{CO}_{3}+1 \% \mathrm{NaCl}$ by increasing the pitting potential and decreasing the passive current densities.

\section{Acknowledgment}

The authors would like to express their sincere appreciation to the Research Affairs at the United Arab Emirates University (UAEU) for their partial support of this project under SURE +2019 . The authors would also like to express their gratitude to the department of chemistry at the UAEU for providing the facilities to carry out this project. The authors would like to thank Professor Nathir Alrawashdeh from the Higher Colleges of Technologies (HCT) for his help with the manuscript.

\section{References}

1. J. Soltis, Corros. Sci., 2015, 90, no. 1, 5-22. doi: 10.1016/j.corsci.2014.10.006

2. A. Veluchamy, D. Sherwood, B. Emmanuel and I.S. Cole, J. Electroanal. Chem., 2017, 785, 196-215. doi: 10.1016/j.jelechem.2016.12.020

3. M. Moreno, W. Morris, M.G. Alvarez and G.S. Duffo, Corros. Sci., 2004, 46, no. 11, 2681-2699. doi: 10.1016/j.corsci.2004.03.013

4. Y.T. Tan, S.L. Wijesinghe and D.J. Blackwood, Corros. Sci., 2014, 88, 152-160. doi: $\underline{10.1016 / j . c o r s c i .2014 .07 .026}$ 
5. N.N. Andreev, I.A. Gedvillo, A.S. Zhmakina, D.S. Bulgakov and S.S. Vesely, Int. J. Corros. Scale Inhib., 2016, 5, no. 4, 319-324. doi: 10.17675/2305-6894-2016-5-4-2

6. I.A. Gedvillo, A.S. Zhmakina, N.N. Andreev and S.S. Vesely, Int. J. Corros. Scale Inhib., 2017, 6, no. 1, 82-90. doi: 10.17675/2305-6894-2017-6-1-7

7. V.S. Sastri, Green Corrosion Inhibitors, John Wiley and Sons, New Jersey, 2011, ISBN 978-0-470-45210-3.

8. J.R. Ambrose, Corrosion, 1978, 34, no. 1, 27-31. doi: 10.5006/0010-9312-34.1.27

9. T. Kodama and J.R. Ambrose, Corrosion, 1977, 33, no. 5, 155-161. doi: $10.5006 / 0010-$ 9312-33.5.155

10. K. Sugimoto and Y. Sawada, Corrosion, 1976, 32, no. 9, 347-352. doi: 10.5006/00109312-32.9.347

11. C.R. Clayton and Y.C. Lu, Corros. Sci., 1989, 29, no. 7, 881-898. doi: $\underline{10.1016 / 0010-}$ 938x(89)90059-0

12. S. Virtanen, B. Surber and P. Nylund, Corros. Sci., 2001, 43, no. 6, 1165-1177. doi: 10.1016/s0010-938x(00)00121-9

13. A.S. Alshamsi, Int. J. Basic Appl. Sci., 2013, 2, no. 4, 303-311. doi: 10.14419/ijbas.v2i4.1129

14. S.A.M. Refaey, Appl. Surf. Sci., 2005, 240, no. 1-4, 396-404. doi: 10.1016/j.apsusc.2004.07.014

15. X. Li, S. Deng and H.Fu, Corros. Sci., 2011, 53, no. 9, 2748-2753. doi: 10.1016/j.corsci.2011.05.002

16. M.R. Ali, C.M. Mustafa and M. Habib, J. Sci. Res. (Rajshahi, Bangladesh), 2009, 1, no. 1, 82. doi: $10.3329 /$ jsr.v1i1.1053

17. A.S. Alshamsi, Int. J. Electrochem. Sci., 2013, 8, no. 1, 591-605.

18. A.S. Alshamsi and A. AlBlooshi, Int. J. Electrochem. Sci., 2019, 14, no. 6, 5794-5812. doi: $10.20964 / 2019.06 .64$

19. Y.T. Tan, S.L. Wijesinghe and D.J. Blackwood, J. Electrochem. Soc., 2017, 164, no. 9, C505-C515. doi: $10.1149 / 2.0501709$ jes

20. G.O. Ilevbare and G.T. Burstein, Corros. Sci., 2003, 45, 1545. doi: 10.1016/s0010938x(02)00229-9

21. D. Dwivedi, K. Lepkova and T. Becker, $R S C A d v ., 2017$, 7, no. 8, 4580-4610. doi: 10.1039/c6ra25094g

22. G.T. Burstein and P.C. Pistorius, Corrosion, 1995, 51, no. 5, 380-385. doi: $\underline{10.5006 / 1.3293603}$

23. H. Wang, Y. Li, G. Cheng, W. Wu, Y. Zhang and X. Li, Int. J. Electrochem. Sci., 2018, 13, no. 5, 5268-5283. doi: 10.20964/2018.06.05

24. Z. Zhang, S. Chen, Y. Li, S. Li and L. Wang, Corros. Sci., 2009, 51, no. 2, 291-300. doi: $\underline{10.1016 / j . c o r s c i .2008 .10 .040}$ 